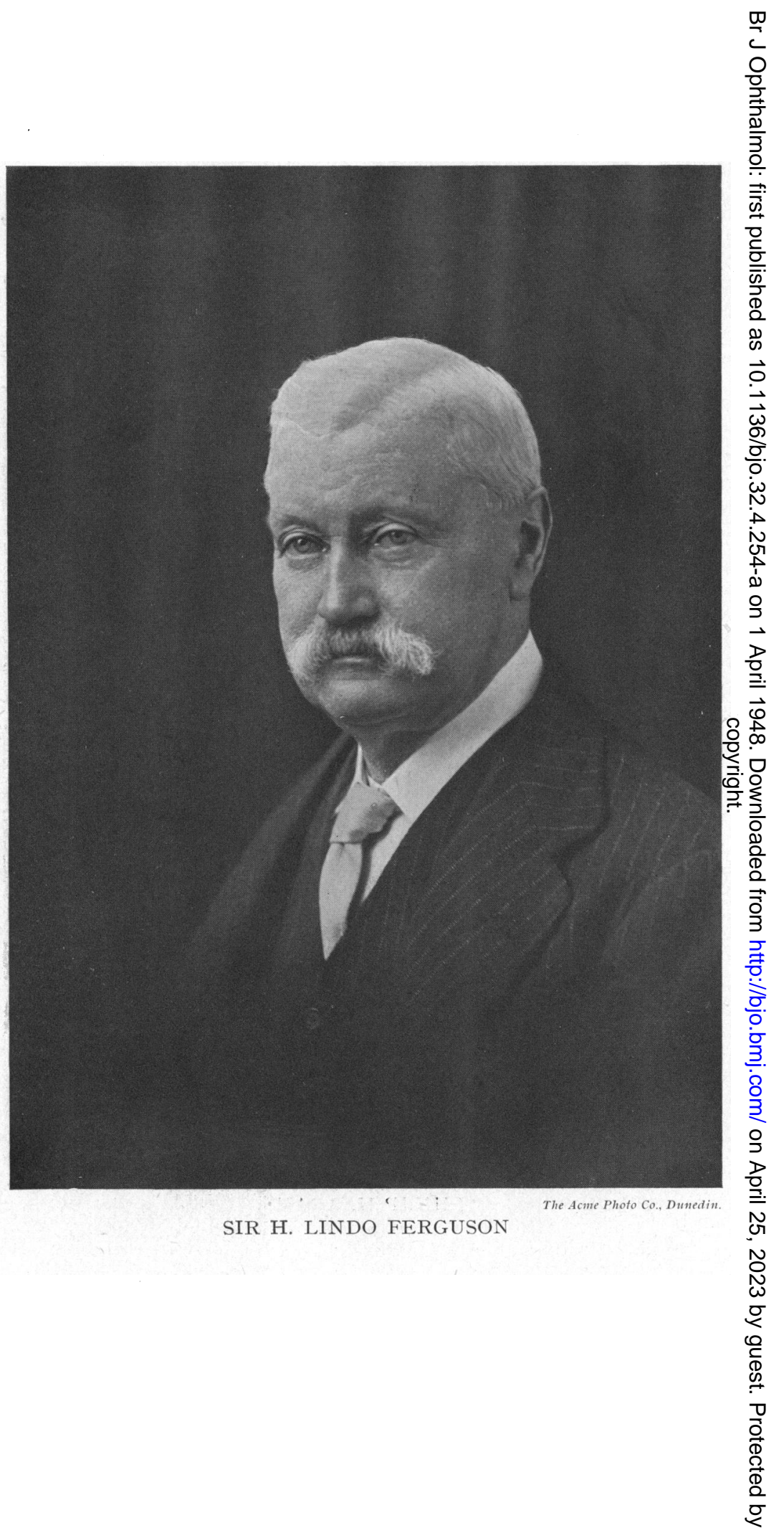


He had great charm of manner, and a most distinguished and handsome appearance. He was always immaculately turned out.

Adams retired from Oxford in 1941 and had made a home in the Eastern Counties, but he attended the Congress each year and it is a sad thought that we shall not see him there again.

\section{SIR H. LINDO FERGUSON}

By the death of Sir Lindo Ferguson on January 22, at Dunedin, New Zealand, the Ophthalmological Society of Great Britain lost its sole surviving foundation member.

Sir Lindo was born in London in 1858. His family moved to Ireland and, in 1873, at the age of 16, he entered the Royal College for Science of Ireland with a Royal Scholarship. He graduated in chemistry and then, turning to medicine, entered Trinity College.

After completing his arts course, he trained at Adelaide Hospital, qualified at the age of 22 and went into residence at St. Mark's Ophthalmic Hospital. After a period of study on the Continent, he held assistantships at various ophthalmic departments and, in 1883, he obtained his Fellowship of the Royal College of Surgeons of Ireland and graduated Doctor of Medicine at Trinity College.

Soon afterwards, for reasons of health, he travelled to New $Z$ ealand, and, finding an embryo medical school in Dunedin, decided to practise there. At this time he was the only ophthalmic surgeon in New Zealand or Australia and very soon his opinion and services were asked for from all quarters. In 1884 he opened the ophthalmic department at Dunedin Hospital and was appointed Lecturer in Ophthalmology two years later. For fifty-two years Sir Lindo served on the staff of the Hospital, always enjoying the esteem of his colleagues, his students and his patients. In 1914 he was appointed Dean of the Medical Faculty, and, realising that the rapidly growing Medical School was woefully lacking in accommodation, he set about the task of rebuilding. Years of hard work for Sir Lindo followed, and 1927 saw the Departments of Anatomy, Physiology, Pathology and Bacteriology all housed in a building which stands as a monument to him.

For twenty years he was a professional representative on the Otago University Council and for eight years a member of the Senate of the University of New Zealand. He was a foundation member of the Ophthalmological Society of the United Kingdom, an original member of the Royal Academy of Medicine in Ireland, an Honorary Fellow of the American College of Surgeons, a Foundation Fellow of the Australasian College of Surgeons, a member of the New Zealand Medical Council and a past President of the New Zealand Branch of the British Medical Association. He was Patron of the New Zealand Ophthalmological Society, founded in 1947. 
Outside his profession he was interested in all good causes, 节ut his chief interest lay, perhaps, in art, and he was President of the? Otago Public Art Gallery Association.

In 1918 , his work for the community was recognised by the ward of the C.M.G., and, six years later, by the bestowal of a Kniglethood.

The words of the present Dean of the Otago Medical Scho $\overline{\bar{e}}$ l sum up the character of one who will long be remembered his colleagues.

"His contribution to Medical education in New Zealand was monumental, and, for a generation, he gave himself unsparingly, without thought of financial reward, to the leadership of the Wedical School. His foresight, wisdom and breadth of vision were oinstrumental in raising the school from obscurity to its present position. His hospitality and kindness to staff, to students, and to patients were proverbial, and benevolence was the keynote of his natutre."

\section{NOTES}

Appointment Air Vice-Marshal P. C. Livingston has been appointed Director-General of the R.A.F. Medical Service $\frac{0}{0} 0$

Edinburgh

Post-Graduate Board for Medicine
A series of post-graduate lectures and ellinical demonstrations on Ophthalmology will ge held during the period May 17 to May 29 \% 1948.

The class is intended for graduates specialising in this subject, and the number will be limited to a maximum of 20 .

The meetings will be held in the Ophthalmic Department $\overline{\text { fof }}$ the Royal Infirmary, Edinburgh. Fee, 8 guineas.

Enquiries and applications for enrolment should be add्के ressed to:-The Director of Post-Graduate Studies, University New Buildings, Edinburgh, 8.

Corrigendum In Mr. Keith Lyle's letter, March, 1948, $\stackrel{\circ}{\text { 予. 191, }}$ the last word of the first paragraph should read "theraps:" not " surgery," as printed.

Sociedad de Oftalmologia This Mexican Society of Ophthalmology was De Guadalojara duly constituted on November 27, श1947: in the prevention of blindness. among its activities will be an active co 